\title{
LAND COVER DYNAMICS OF OLESHKY SANDS: TIME-SERIES ANALYSIS 1987-2017
}

\author{
V. Bogdanets, Assoc. Prof., Cand. Agr. Sci. \\ Email:v_bogdanets@nubip.edu.ua
}

Oleshky Sands is the largest expanse of sand in Ukraine and the second in Europe. In the beginning of XX century sands moving outside of arenas was almost stopped by planting trees (Pinus nigra ssp. pallasian and Pinus sylvestris L.), and the territory had different use during the years. A 30-year (1987-2017) time series of Landsat imagery obtained via USGS geoservice was used to reveal land cover dynamics of deserted landscapes of Oleshky sands using QGIS software. Heavy sand storms can impact nearby settlements and expose harmful effect on local industry and quality of life of local communities. Forest fire is another dangerous factor for protective forest plantations during last years. Our estimation shows that sandy areas increase during 2000-2017; generally, conservation measures had constant effect despite afforestation of last years. The preventive effect of forest on sands moving at Oleshky sands can be characterized as stable in case of constant care about the forest plantation and proper documentation on land use and ownership.

Keywords. Combating desertification, landscapes dynamics, land cover change, QGIS, Landsat imagery

\section{Introduction.}

Oleshky Sands is the largest expanse of sand in our country and the second in Europe after Ryn desert in Western Kazakhstan and Kalmykia. Its area estimated as 161.2 sq. km, main part is about 15 $\mathrm{km}$ in diameter [1]. It is situated in inland Ukraine in Kherson region near the mouth of Dnipro river and coast of Black Sea (fig.1) and consists of dunes of sand up to five meter height. It is classified as semidesert region according to temperature and moisture regime [2]. A lot of sparse vegetation is located across these sands, at spring even some wetland and swamp area can occur. At summer air temperature rises to $40^{\circ} \mathrm{C}$ and more.
State natural reserve "Oleshky sands" was created in 2010 with total area of 8020.36 ha, it is a nature conservation, recreation, cultural, educational and research institution of national importance and a part of the nature reserve fund of Ukraine [4].

In XX century moving sands appear a great danger to local settlements and agriculture, then this was limited by planting a massive of trees (mainly Pinus nigra ssp. pallasian, and Pinus sylvestris L.) around sandy arenas. Now territory is surrounded (mainly on the south) by dense forest planted to prevent dunes moving. In summer this forest often catches fire as can be seen from satellite imagery. Underground 


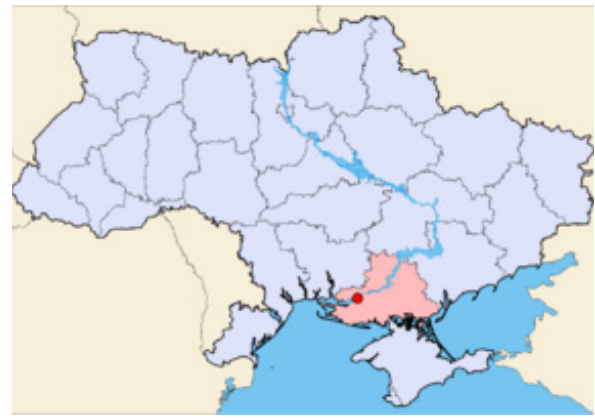

Fig.1. Location of research territory.

water reserve forms an important part of all local environment as a source of fresh water [5].

There are different hypotheses of reason why this territory became a semi-desert: massive geological events of ice age, meteorite crater, drying of old Dnipro riverbed, but the most common is that it was a great pasture for more than a million sheep in 18-19 centuries, then forest fires, wind erosion made a semidesert here on eolian and alluvial sands as a good geological precondition. Anyway, there are no evidence of desert before 1800 s in historical documents. In XX century this place was used as military polygon [5]. Aim of research - by comparison of 30-year time series of Landsat data on research territory analyze trends in land cover change and reveal drivers of such changes.

\section{Methods and materials.}

USGS data from Landsat-5 and Landsat- 8 were used to build time series for research object, main images of series were: 04 October 1987, 18 September 1993, 12 September 2000, 15 September 2006, 20 September 2011, and LT8 for 30 September 2017, as cloud percentage was less than $10 \%$ in these dates. This season was chosen due to relative perennial stability of landscapes and low danger of forest fires. QGIS 2.18 and GDAL tools were used to process image data. Public cadastral map of Ukraine using QuickMapSer-

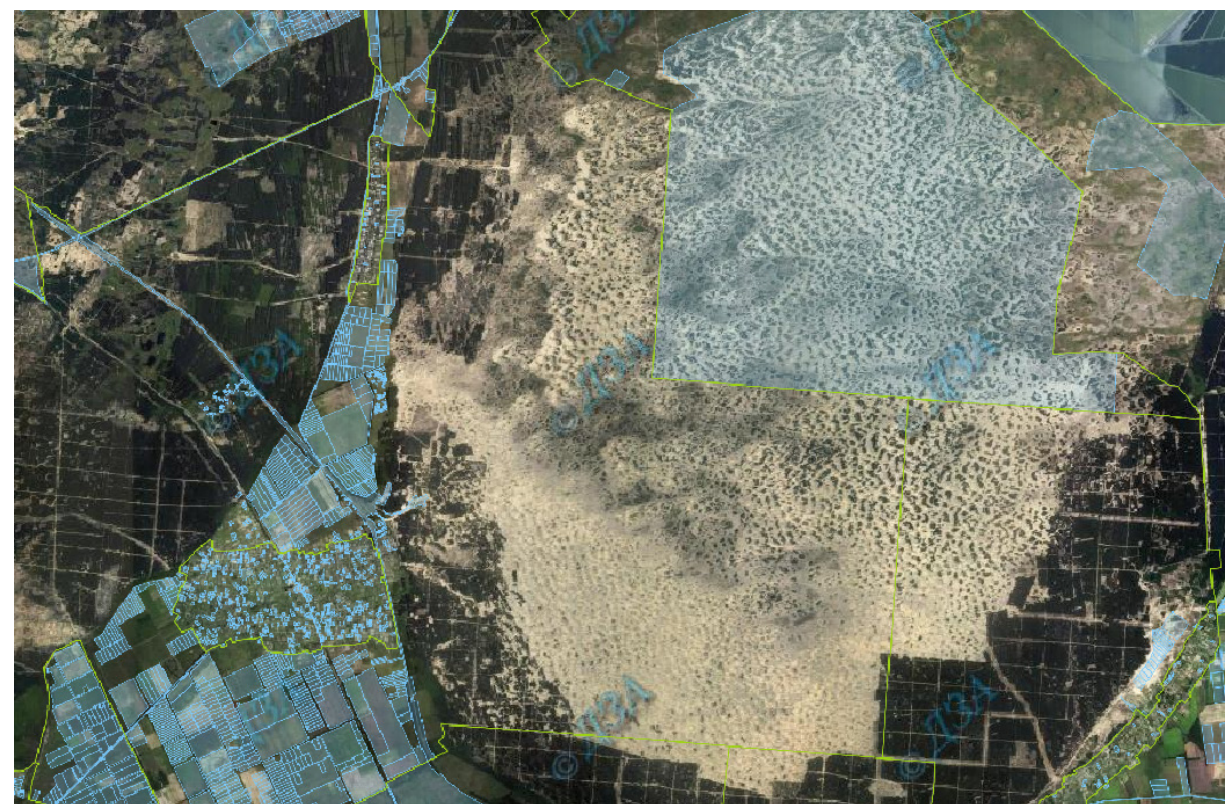

Fig.2. Oleshky sands on the Public cadastral map of Ukraine [6]. 

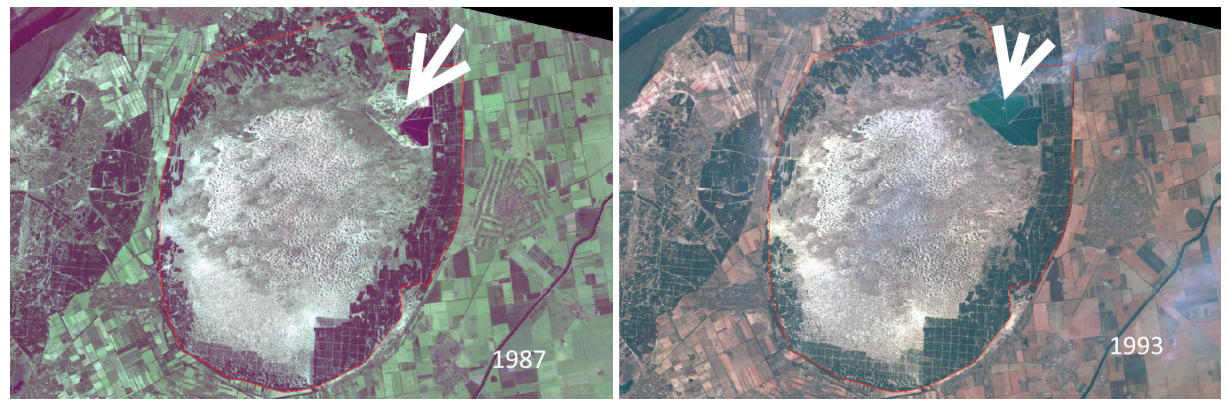

Fig. 3. Major land cover changes for period 1987-1993.

vices plugin in QGIS was used to access information about cadastral plots in research object.

\section{Results and discussion.}

One of main tasks of our research was to assess land ownership and current land use. Public cadastral map of Ukraine [6] shows that state property on land of national reserve is not formed properly as the whole territory. The central plot of 5378.6087 ha and smaller
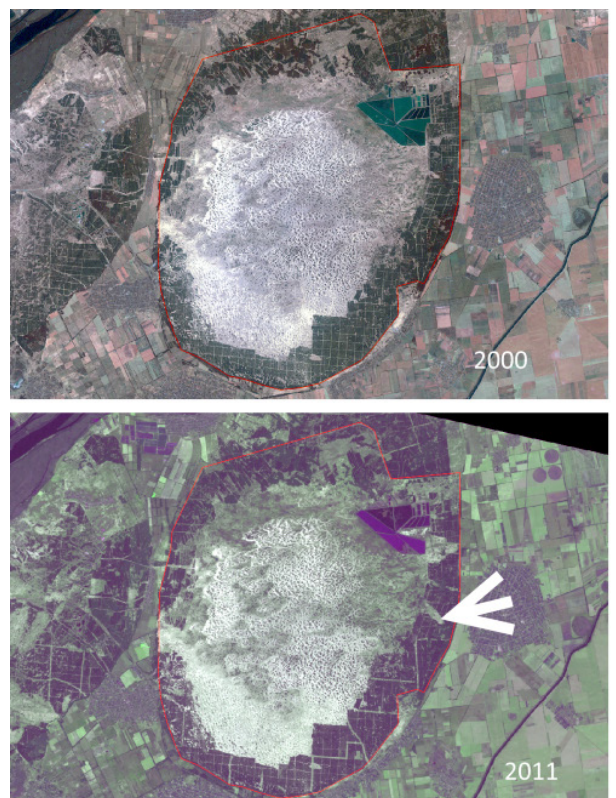

Fig. 4. Major land cover changes for period 2000-2017.
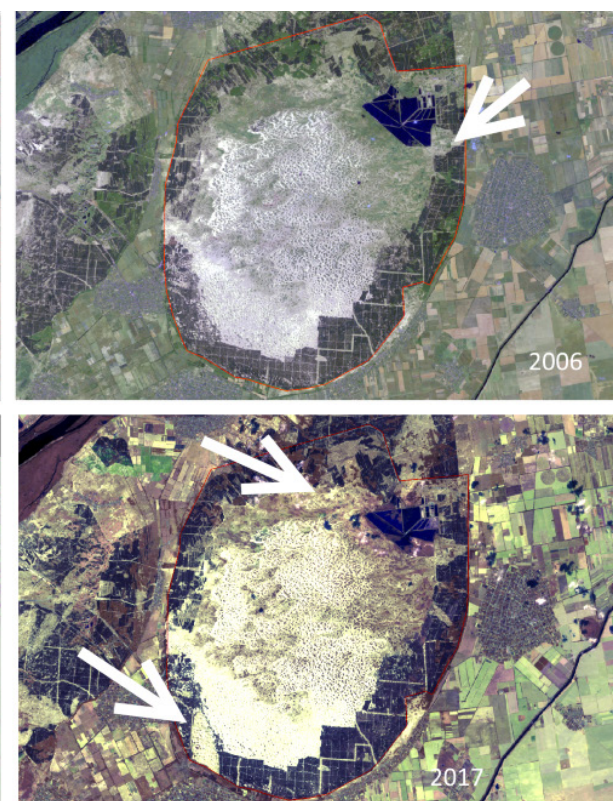

area to the east of 468 ha are of state property, smaller ones show parcels of private property in a very close proximity to moving sands (fig.2).

A time-series of Landsat images allows us to form a picture of land cover changes of the research area for 30 years. Main changes were connected to increase of sandy areas. The 30-year period was divided for shorter, which display major changes (fig.3, 4).

As main change for period 19871993, it can be admitted that reservoirs 
for fishery at the north-east part was fully filled (fig.3, shown by arrow), while sands were almost constant by area; main reason - balanced land and water management.

Next 17-years period shows expansion of sand on the north-eastern and south-western sides of the arena (fig.4, shown by arrows). Comparing to 2006, on 2011 image a medium sized sand massive appeared (shown by arrow). This period shows evidence of decreasing forest and big sand storms in the south-western part in 2016-2017 (shown by arrows), where forest protection effect was not strong enough supposedly due to poor state of control [3].

On our opinion, the main reasons for imbalance of landscapes for this period are: improper land management, forest fires and lost of good care of forest plantations around the sand arena.

Further research needed to show development of processes of landscape change and a stabilized land use can be achieved in case of control of forest protection plantations around the sand arena. That is impossible without connection with proper formed rights for state land use.

\section{Conclusions.}

A 30-year (1987-2017) time series of Landsat imagery obtained via USGS geoservice was used to reveal land cover dynamics of deserted landscapes of Oleshky sands using QGIS software. Heavy sand storms can impact nearby settlements and expose harmful effect on local industry and quality of life of local communities. Forest fire is another dangerous factor for protective forest plantations during last years. Our estimation shows that sandy areas increase during 2000-2017; generally, conservation measures had constant effect despite afforestation of last years. The preventive effect of forest on sands moving at Oleshky sands can be characterized as stable in case of constant care about the forest plantation. That is impossible without connection with proper formed rights for state land use.

Next stage of our research will include detailed quantitative and qualitative estimation of landscape changes and improved range of data time-series.

\section{References}

1. Network of the European Dry Grassland Group. "Bull. Eur. Dry Grassl. Group, No 8., 2010. URL http://d-nb. info/1010626833/34/

2. Fehmi, J. S., Niu, G. Y., Scott, R. L., Mathias, A. Evaluating the effect of rainfall variability on vegetation establishment in a semidesert grassland. Environmental monitoring and assessment, 186, Vol.1, 2014. - P. 395-406.

3. Malchykova, D., A. Ponomareva, R. Molikevych. "Environmental protection and spatial planning of eco-net strategies in regions with high level of anthropogenic transformation of geosystems." Scientific Journal of Kherson state university. Series: Geography. Vol. 2, 2015. - P. 92-107.

4. National state reserve "Oleshky sands". Official site URL https://nppop.gov.ua/

5. Oleshky Sands. Wikipedia. URL: https:// en.wikipedia.org/wiki/Oleshky_Sands

6. Public Cadastral Map of Ukraine. URL http://map.land.gov.ua/kadastrova-karta [for 27 October 2017].

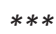

Богданець B.A., ДИНАМІКА ЗЕМЛЕКОРИСТУВАННЯ ОЛЕШКІВСЬКИХ ПІСКІВ: АНАЛІЗ ЧАСОВОГО РЯДУ 1987-2017 РP.

Олешківські піски - найбільший піщаний масив України, друга за розмірами пустеля Європи. На початку 20 століття 
рухомі піски, які спричиняли значні збитки місцевого населення та промисловості, були практично зупинені лісозахисними насадженнями Сосни кримської та Сосни звичайної, територія у иі роки використовувалася за різноманітним призначенням. 30-річний ряд (1987-2017) супутникових знімків Ландсат, отриманих із сервісів USGS, використовувався нами у програмі QGIS для відстеження динаміки опустелених ландшафтів. Сильні піщані бурі та лісові пожежі і зараз можуть чинити значний вплив на місцеву промисловість та сусідні поселення. За нашими оцінками, у період 2000-2017рр. площі піщаних земель зросли, хоча загалом лісові насадження мали стабільний ефект незважаючи на зменшення плоші лісів останні роки. Захисний ефект лісових насаджень на запобігання руху пісків можливий за умови строгого контролю стану цих насаджень та належного оформлення права на землекористування.

Ключові слова: боротьба з опустелюванням, динаміка ландшафтів, зміни вкритmя, QGIS, знімки Landsat.

Богданеч, В.А.

ДИНАМИКА ЗЕМЛЕПОЛЬЗОВАНИЯ ОЛЕШКОВСКИЕ ПЕСКИ: АНАЛИЗ ВРЕМЕННОГО РЯДА 1987-2017 ГГ.
Олешковские пески - самый большой песчаный массив Украины, вторая по величине пустыня Европы. В начале 20 века подвижные пески, которые вызывали значительные убытки местного населения и промышленности, были практически остановлены лесозащитными насаждениями Сосны крымской и сосны обыкновенной, территория в эти годы использовалась по разнообразным назначением. 30-летний ряд (1987-2017) спутниковых снимков Ландсат, полученных из сервисов USGS, использовался нами в программе QGIS для отслеживания динамики опустыненных ландшафтов. Сильные песчаные бури и лесные пожары и сейчас могут оказывать значительное влияние на местную промышленность и соседние поселения. По нашим оценкам, в период 2000-2017рр. площади песчаных земель возросли, хотя в целом лесные насаждения имели стабильный эфррект несмотря на уменьшение площади лесов последние годы. Защитный эфрект лесонасаждений на предотвращение движения песков возможен при условии строгого контроля состояния этих насаждений и надлежащего оформле ния прав на землепользование.

Ключевые слова: борьба с опустынива нием, динамика ландшафтов, изменения поверхностного укрытия, QGIS, снимки Landsat. 